\title{
Effects of Saline and Sodic Stress on Yield and Fatty Acid Profile in Sunflower Seeds
}

\author{
Giovanna Cucci ${ }^{*}$, Taddeo Rotunno ${ }^{2}$, Antonio De Caro ${ }^{2}$, Giovanni Lacolla ${ }^{1}$, \\ Roberto Di Caterina ${ }^{2}$, Emanuele Tarantino ${ }^{2}$ \\ ${ }^{1}$ Dipartimento di Scienze delle Produzioni Vegetali, Università di Bari \\ Via Amendola 165/A, 70125 Bari, Italy \\ ${ }^{2}$ Dipartimento di Scienze Agroambientali, Chimica e Difesa Vegetale, Università di Foggia \\ Via Napoli 25, 71100 Foggia, Italy
}

Received: 27 January 2006. Accepted: 5 May 2006

\begin{abstract}
Among the objectives concerned in this research, much importance has been attached to the assessment of the influence of soil type, irrigation water quality and leaching requirement on the production and composition in fatty acids of sunflower oil. The trial was run in 2001 on a sunflower crop (cv. HS 90) grown in cylindrical pots at the Campus of Bari University (Italy). 36 treatments obtained from the factorial combination of two clay soils with nine types of brackish water and two leaching fractions (10 and 20\%) were compared. The nine types of irrigation water were obtained by dissolving the proper amounts of $\mathrm{NaCl}$ and $\mathrm{CaCl}_{2}$ in de-ionized water, according to the factorial combination of three salt concentration levels $(0.01,0.032$ and $0.064 \mathrm{M})$ with three sodium levels $(\mathrm{SAR}=5$, 15 and 45). At ripening the main yield traits, oil yield and acid composition of seeds were analysed. At the highest salinity level about $70 \%$ yield reduction, in terms of seeds per plant was observed. The oil yield and the final acid composition of seeds were significantly affected by soil type, leaching requirement, salinity and the SAR levels of irrigation water. A progressive decline in oil yield was recorded as the salt concentration and sodium level of irrigation solutions increased. As to the fatty acid composition, a gradual increase in oleic and linolenic acid content and a corresponding decrease in the other fatty acids were found as the salinity and sodium levels of irrigation water increased. The oleic/linoleic acid ratio too increased as the salinity increased. The salt and sodium-induced stresses of irrigation water reduced the seed and oil yields while still favouring a progressive increase in the oleic acid content and a slight decrease of linoleic, palmitic and stearic acids, thus improving oil quality. The results point out both the influence of the soil and the positive effect of sodium and salt stress and of the leaching fraction on the food quality of sunflower oil.
\end{abstract}

Key-words: sunflower oil quality; sodic-saline stress, soil type, leaching.

\section{Introduction}

The oil of conventional sunflower varieties is characterised by the predominance of two unsaturated acids, the oleic $(18: 1)$ and linoleic (18:2) acids, which account for over $90 \%$ of the total fatty acids. The remaining share is mostly represented by the palmitic (16:0) and stearic (18:0) saturated acids; other acids with a number of carbon atoms lower than 16 or higher than 18 are found in minute weight percent values or just as traces.

The relative incidence of the two predominant acids, and their ratio, are highly variable depending on the climatic conditions of the oilproducing environments. The biosynthesis of these fatty acids is indeed regulated by the temperature pattern in the seed development and filling stages: high temperatures favour the oleic acid formation, whereas low temperatures induce a higher accumulation of linoleic acid (Tremolières and Jacques, 1984). This acid forms from the oleic acid by carbon de-saturation in position 12 catalysed by the enzyme $\Delta-12$ desaturase, whose activity is stimulated by low temperatures.

The oil content in linoleic acid is therefore inversely correlated to the mean minimum tem- 
perature of the seed formation stage (Robertson et al., 1978; Anastasi et al., 2001). This explains both the differences in the oleic/linoleic ratio between oils produced in different geographical areas, and the progressive increase of the linoleic acid content in the oils produced from environments in which the latitude, altitude and distance from the sea induce increasingly lower minimum temperature values (Lajara et al., 1990). Similar values are observed by postponing the sowing time from spring to full summer, as a consequence of the deferment of the seed production period towards late summer and autumn, characterised by progressively decreasing temperatures (Jones, 1984; Cilardi et al., 1990).

The differences in the acid composition may be effectively exploited for specific oil uses in food and industry. For example, the oils rich in linoleic acid that are more fluid are suitable for the production of margarine spread and dressing; the oils rich in oleic acid, instead, are more suitable for cooking and/or frying, for the high smoke point and stability to oxidation, and pyrolysis at very high temperatures. The lower degree of insaturation gives to this type of oils the ability to keep its properties long unchanged over time.

In human nutrition, the nutritional profile of sunflower oil offers an interesting possibility to further increase the large use of this crop for the positive role of mono-unsaturated fatty acids in preventing cardio-vascular diseases. Actually a diet rich in oleic acid and with high oleic/linoleic and (stearic + oleic)/palmitic ratios reduces the rate of cholesterol associated with low-density lipoproteins, namely the LDL cholesterol, responsible for the formation of arteriosclerotic plaque in blood vessels (Grundy, 1986; Miller et al., 1987; Yodice, 1990; Grummer, 1991).

The results of research reported in the literature indicate that the agronomic management that favours seed and oil productivity improves the oleic acid content as well (Monatti, 2002). In particular, in relation to this acid and its ratio to the linoleic acid, the effect of nitrogen fertilisation has not resulted to be significant (Pritoni et al., 1999; Sifola et al., 2005); on the contrary, clear effects have been observed as related to the temperature (Garcès et al., 1989; Anastasi et al., 2000), the sowing time (Pritoni et al., 1999; Anastasi et al., 2000, 2001), the incorpo- ration of increasing rates of wet pomace (Cucci et al., 2005), the varieties (Monotti et al., 1999, Laureti et al., 2000; Monotti 2004) and the water supply (Baldini et al., 1999, 2000; Santonoceto et al., 1999; Santonoceto et al., 2003). Water stress accelerates the embryo development and the lipid accumulation and it has a significant and beneficial effect on the oleic acid content at harvest, as compared to the other treatments (about $5 \%$ increase) (Baldini et al., 2002).

Although the sunflower is a moderately salt tolerant crop (Francois, 1996), the salt stress effect has been largely tested only on the unit yields of seeds and oil (Tedeschi et al., 1997; Rivelli and Albrizio 2005; Rivelli and Coccaro 2005); the acid composition, instead, has been little investigated (Baldini et al., 1999; Flagella et al., 2002). The effects of the soil type, the leaching requirement and the irrigation water sodium content are still unknown and need to be studied. The aim of this paper is to obtain more information on the effect of irrigation waters of different salt concentrations and SAR values on the production and acid composition of oil in a sunflower hybrid.

\section{Materials and methods}

The trial was run in 2001, at the Campus of the Agricultural Faculty of Bari University (Italy), within a long-term research aimed at testing the cumulative effect over time of irrigation waters of different salt concentrations and SAR values on crops in succession, grown on two soil types submitted to two different leaching requirements. The 2 soil types, both rich in clay material and non saline at the start of the trial (1999), are different, one being poor in iron and aluminium sesquioxides, and non-calcareous (B) (taken from the AP horizon of a Udertic fine Ustochrept, mixed mesic, Montefalcone series on the Emilia-Romagna soil map, northern Italy); the other containing more kaolin, calcareous and rich in sesquioxides (L) (taken from the AP horizon of Pachic Haploxeroll, mixed, thermic, Cutino series on the Apulia soil map, southern Italy) (Ta. 1).

For 4 years on hand, the 2 soils contained in cylindrical pots $(0.2$ and $1.0 \mathrm{~m}$ in size and height respectively in the first two years, and 0.4 and $0.6 \mathrm{~m}$ in the second two-year period) supplied 
Table 1. Main properties of the soils before salt application in 1999.

\begin{tabular}{|c|c|c|}
\hline & $B$ & $\mathrm{~L}$ \\
\hline Total Nitrogen (Kjeldahl method) (g1000 g-1) & 0.79 & 1.65 \\
\hline Available phosphorus (Olsen method.) (mg kg-1) & 31.50 & 52.50 \\
\hline Exchangeable potassium (amm. acetate method) $\left(\mathrm{mg} \mathrm{kg}^{-1}\right)$ & 160.00 & 352.00 \\
\hline Organic matter (Walkley Black method.) (g $100 \mathrm{~g}^{-1}$ ) & 1.21 & 3.13 \\
\hline Total limestone ( $\left.\mathrm{g} 100 \mathrm{~g}^{-1}\right)$ & 0.47 & 2.58 \\
\hline Active limestone (g $\left.100 \mathrm{~g}^{-1}\right)$ & 0.05 & 1.40 \\
\hline $\mathrm{pH}\left(\mathrm{pH}\right.$ in $\left.\mathrm{H}_{2} \mathrm{O}\right)$ & 7.09 & 7.18 \\
\hline $\mathrm{ECe}(\mathrm{dS} \mathrm{m})^{-1}$ & 0.65 & 0.78 \\
\hline ESP & 0.70 & 0.80 \\
\hline $\mathrm{CEC}\left(\mathrm{BaCl}_{2}\right.$ method) (meq $100 \mathrm{~g}^{-1}$ of dry soil) & 29.54 & 31.61 \\
\hline Total sand $\quad 2>\mathrm{f}>0.02 \mathrm{~mm}\left(\mathrm{~g} 100 \mathrm{~g}^{-1}\right)$ & 30.27 & 20.94 \\
\hline Silt $\quad 0.02>\mathrm{f}>0.002 \mathrm{~mm}\left(\mathrm{~g} 100 \mathrm{~g}^{-1}\right)$ & 33.10 & 44.00 \\
\hline Clay $\quad \mathrm{f}<0.002 \mathrm{~mm}\left(\mathrm{~g} 100 \mathrm{~g}^{-1}\right)$ & 33.63 & 35.06 \\
\hline Field capacity (g $100 \mathrm{~g}^{-1}$ of soil dry mass) & 34.50 & 35.80 \\
\hline Wilting point $(-1.5 \mathrm{MPa})\left(\mathrm{g} 100 \mathrm{~g}^{-1}\right.$ of soil dry mass) & 14.70 & 18.40 \\
\hline Bulk density $\left(\mathrm{t} \mathrm{m}^{-3}\right)$ & 1.20 & 1.20 \\
\hline
\end{tabular}

with a bottom valve for drainage water collection and located under shed to prevent the leaching action of rainfall, grown with fat round bean in 1999, green pepper in 2000, sunflower in 2001 and wheat in 2002, were irrigated with 9 different types of water and submitted to 2 different leaching requirements (L.R. $=10$ and $20 \%$ ). The 9 types of water were obtained by dissolving the proper amounts of $\mathrm{NaCl}$ and $\mathrm{Ca}$ $\mathrm{Cl}_{2}$ in de-ionised water, so as to combine factorially 3 salt concentration levels $(0.001,0.01,0.1$ $\mathrm{M}$ for bean in 1999; 0.01, 0.032, 0.1 $\mathrm{M}$ for green pepper in 2000 and $0.01,0.032,0.064 \mathrm{M}$ for sunflower in 2001 and wheat in 2002), with 3 SAR levels $(5,15,45)$ (Tab. 2).

The 36 treatments obtained from the factorial combination of the 2 soil types, with the 9 types of water and the 2 L.R. levels were compared for each year. The split plot experimental design with 2 replicates was applied, with the

Table 2. Salt concentration, electrical conductivity (EC) and SAR of the solutions used to irrigate the sunflower crop.

\begin{tabular}{crrlrr}
\hline $\begin{array}{l}\text { Types of } \\
\text { Solutions }\end{array}$ & $\begin{array}{c}\mathrm{NaCl} \\
\left(\mathrm{mg} \mathrm{l}^{-1}\right)\end{array}$ & $\begin{array}{r}\mathrm{CaCl}_{2} \\
\left(\mathrm{mg} \mathrm{l}^{-1}\right)\end{array}$ & $\mathrm{M}$ & $\begin{array}{c}\mathrm{ECw} \\
\left(\mathrm{dS} \mathrm{m}^{-1}\right)\end{array}$ & $\mathrm{SAR}$ \\
\hline 1 & 447.42 & 260.26 & 0.01 & 1.45 & 5 \\
2 & 560.54 & 45.39 & 0.01 & 1.24 & 15 \\
3 & 581.57 & 5.47 & 0.01 & 1.19 & 45 \\
4 & 1076.71 & 1507.29 & 0.032 & 4.65 & 5 \\
5 & 1660.49 & 398.32 & 0.032 & 3.86 & 15 \\
6 & 1841.52 & 54.43 & 0.032 & 3.59 & 45 \\
7 & 1712.38 & 3852.53 & 0.064 & 11.30 & 5 \\
8 & 3039.04 & 1332.24 & 0.064 & 9.60 & 15 \\
9 & 3629.31 & 181.38 & 0.064 & 8.95 & 45 \\
\hline
\end{tabular}

soil types in large plots (18 pots), the leaching requirements in sub-large-plots ( 9 pots) and the types of water in plots (single pots).

The sunflower sowing was performed on 24.04.2001 by placing one seed per pot of the hybrid (HS 90), chosen among the conventional ones for its greater adaptability to adverse conditions. At sowing the 2 soil types were characterised by a mean ECe ranged between 2.1 and $12.8 \mathrm{dS} \mathrm{m}^{-1}$ in relation to the salt concentration of the irrigation water used in the previous two-year period.

Just after sowing in order to favour seed germination and plantlet emergence, the crop was irrigated with water characterised by a salt concentration of $0.01 \mathrm{M}$ and an SAR equal to 5 . Since plantlet emergence till the end of the irrigation season, the 9 types of water were used, irrigating whenever $30 \%$ of the maximum available moisture was lost by evapotranspiration. The applied water corresponded to the volume required to restore the field capacity in the whole soil mass contained in each pot, plus the calculated leaching fraction.

The plant management was applied following the local cultural practices. At harvest, on 6 August 2001, the following yield and quality parameters were tested: seed weight per head, 1000 seed weight, number of seeds per head, head diameter, oil yield and fatty acid content.

\subsection{Oil extraction}

The seeds were oven-dried at $40{ }^{\circ} \mathrm{C}$ for $4 \mathrm{~h}$, by using a ventilated vacuum oven, up to a mois- 
ture content of about 5\%; then they were ground with a Waring Blendor (Waring Product Division, New Hartford, CT, USA). The meal was extracted with petroleum ether for $6 \mathrm{~h}$ in a Soxhlet type extractor. The oil extract was evaporated by distillation at reduced pressure (15 Torr) in a Rotary evaporator (Heildof) at $35^{\circ} \mathrm{C}$ until the solvent was totally removed. Crude extracts were then weighed.

\subsection{Analysis of total fatty acids}

An aliquot of $2 \mathrm{~g}$ of sunflower seed oil was transferred to a screw capped vial with $0.3 \mathrm{~mL}$ methanol-sodium methilate (28.5:1.5 by weight) and held at $90^{\circ} \mathrm{C}$ for $2 \mathrm{~h}$ for methilation of the oil fatty acids. The fatty acid composition of sunflower oil was determined (Flagella et al., 2002) using a Fisons model GC-8160 gas chromatograph (Italian Fisons, I-20100 Milan, Italy). Peak identification was performed by comparing the relative retention times with those of a commercial standard mixture (Larodan) of fatty acid methyl esters (FAME).

\subsection{Statistical analysis}

The data set, with 2 repetitions, consisted of 72 cases (oil samples) and 14 variables (9 fatty acids, oil yield, seed yield, 1000 seed weight, seeds per head, head diameter). The samples were classified in 36 groups, according to the treatments used on the sunflower plants obtained by the factorial combination of 2 clay soils with 9 types of irrigation brackish waters and 2 leaching fractions.

Principal component analysis (PCA) was used to explore the influence of soil type, irrigation water quality (salt concentration and SAR), and leaching requirement on the fatty acid profile plus oil yield. This multivariate method is used for preliminary analysis to acquire a general view of the problem (Massart et al., 1988). The results of PCA can be graphically represented in two-dimensional plots (Fig. 1), showing the relationships among variables (loading plot), among cases (score plot), and between cases and variables. PCA reduces the number of variables according to their redundancy, and finds the components as linear combinations of the variables, with the first principal component having the largest variance (or information), the second principal component with the second largest variance, and so on. Be- fore applying this method it was necessary to autoscale the data set in order to equalize the variance of the different factors.

All the 14 variables were tested for normal distribution using the Shapiro-Wilk test, and subjected to an analysis of variance for testing the variations due to soil type, water quality, leaching requirements, and their interactions, using the GLM procedure for repeated measures in the SAS statistical software. Since the effects of the interactions of the categorical factors were significant only in very few cases, only those due to the different treatments are reported in the tables. Differences between means were compared according to the Student-Newman- Keuls test. $\mathrm{P}<0.05$ was considered significant unless otherwise stated.

Analysis of variance was applied to two more variables for the fatty acid ratios oleic/ linoleic and (oleic + stearic)/palmitic.

\section{Results and discussion}

\subsection{Principal components analysis}

Figure 1 shows the combined plot of the scores of the oil samples and the loads of the fatty acids plus oil yield onto the plain of the first two principal components displaying $62.2 \%$ of

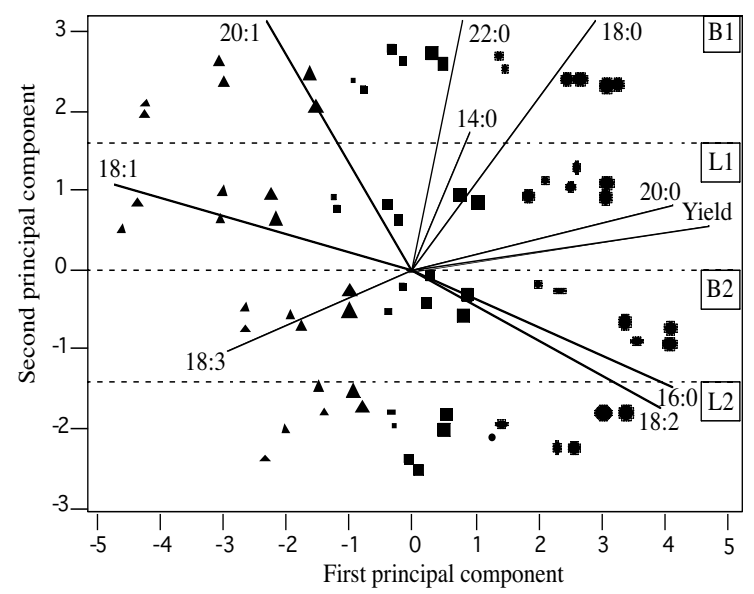

Figure 1. Principal Component Analysis of the fatty acids plus yield of the sunflower oil samples analysed. The 72 oil samples were divided in 4 groups of 18 ( 2 repetitions $\mathrm{x} 9$ types of irrigation obtained from 3 final salt concentrations, $0.01 \mathrm{M}(\bullet), 0.032 \mathrm{M}(\boldsymbol{\bullet})$ and $0.064(\boldsymbol{\Delta}) \mathrm{M}$, each with 3 sodium levels (SAR): $5(\bullet, \boldsymbol{\bullet}, \mathbf{\Lambda}), 15(\bullet, \boldsymbol{\bullet}, \mathbf{\Lambda})$ and $45(\bullet, \bullet, \mathbf{\Lambda})$, respectively) according to the 2 clay soils ( $\mathrm{L}$ and $\mathrm{B}$ ) where the crops grew, each submitted to two leaching fractions $10 \%$ (1) and $20 \%(2)$. 
Table 3. Effects of the soil type (B, L), leaching requirement (L.R.), salt concentration and SAR of irrigation water on the major yield components and oil and seed yields.

\begin{tabular}{|c|c|c|c|c|c|c|c|c|c|c|}
\hline \multirow{2}{*}{$\begin{array}{l}\text { Yield } \\
\text { Parameters }\left({ }^{1}\right)\end{array}$} & \multicolumn{2}{|c|}{ Soil types } & \multicolumn{2}{|c|}{ L.R. (\%) } & \multirow[b]{2}{*}{0.01} & \multicolumn{3}{|c|}{ Concentration (M) } & \multicolumn{2}{|l|}{ SAR } \\
\hline & B & $\mathrm{L}$ & 10 & 20 & & 0.032 & 0.064 & 5 & 15 & 45 \\
\hline Seed yield (g plant ${ }^{1}$ ) & $30.0 \mathrm{~B}$ & $32.0 \mathrm{~A}$ & 29.7B & $33.1 \mathrm{~A}$ & $44.3 \mathrm{~A}$ & $39.0 \mathrm{~B}$ & $10.8 \mathrm{C}$ & $30.9 \mathrm{~A}$ & $31.8 \mathrm{~A}$ & $31.4 \mathrm{~A}$ \\
\hline 1000 seed weight $(\mathrm{g})$ & $36.1 \mathrm{~A}$ & $31.8 \mathrm{~B}$ & $33.3 \mathrm{~B}$ & 43.7A & $41.5 \mathrm{~A}$ & $39.4 \mathrm{~B}$ & $21.1 \mathrm{C}$ & $34.3 \mathrm{~A}$ & $34.2 \mathrm{~A}$ & $33.5 \mathrm{~B}$ \\
\hline Seeds per head (n) & 886B & 969A & $892 B$ & $954 \mathrm{~A}$ & 1067A & 990B & $512 \mathrm{C}$ & 901B & $930 \mathrm{~A}$ & 937A \\
\hline Head diameter $(\mathrm{cm})$ & $11.0 \mathrm{~A}$ & $11.7 \mathrm{~A}$ & $11.2 \mathrm{~A}$ & $11.5 \mathrm{~A}$ & $13.4 \mathrm{~A}$ & $12.8 \mathrm{~B}$ & $7.8 \mathrm{C}$ & $11.2 \mathrm{~A}$ & $11.3 \mathrm{~A}$ & $11.5 \mathrm{~A}$ \\
\hline Oil yield $(\%)$ & $44.5 \mathrm{~A}$ & $42.4 \mathrm{~B}$ & $43.1 \mathrm{~B}$ & $43.6 \mathrm{~A}$ & $50.2 \mathrm{~A}$ & $46.1 \mathrm{~B}$ & $35.4 \mathrm{C}$ & $44.8 \mathrm{~A}$ & $43.5 \mathrm{~B}$ & 41.9C \\
\hline
\end{tabular}

$\left.{ }^{1}\right)$ For each effect considered, the values followed by the same letter are not significantly different, according to the SNK test at $\mathrm{P} \leq 0.01$.

total variance. This projection of the objects allowed identifying four distinct groups, each comprising the oil samples classified according to soil type and leaching requirement. The samples in each of these groups were separated in 9 subgroups and shifted from right to left along the first component (describing $48.8 \%$ of total variance), according to the increasing values of both salt concentration and SAR level. These separations of the examined oil samples mean that type of soil with different leaching fractions and irrigation with water of different salt concentration and SAR values affected the fatty acid composition in the sunflower oil.

The plot of the loadings of the measured fatty acids emphasized the role of each variable in separating the groups. The plants irrigated with lower salt content water were characterized by higher contents of palmitic, arachidic, linoleic and stearic acids, and higher oil yield; the plants irrigated with water of higher salt content had higher contents of oleic, linolenic and eicosenoic acids. The non-calcareos soil $\mathrm{B}$ and the lower leaching fraction yielded oil richer in stearic, eicosenoic, and behenic acids; the calcareous soil $\mathrm{L}$ and the higher leaching fraction yielded oil richer in linoleic, palmitic and linolenic acids.

\subsection{Analysis of variance}

Tables 3 and 4 report the ANOVA results applied to the experimental data. No significant difference in terms of length of sunflower growth stages as related to the soil type and salt stress was observed; this is neither the case of other species, in which this kind of stress induces a shortening in reproductive phases (Francois, 1982; Francois et al., 1986) nor of sunflower under water stress conditions (Quaglietta Chiarandà and D'Andria, 1994).
The seed yield and fatty acid composition, instead, point out significant differences related to the soil type, the leaching requirement, the salt concentration and the SAR of irrigation water; the ANOVA did not reveal any significant result for the soil type $\mathrm{x}$ water type interaction.

\subsection{Effects of soil type and leaching requirement}

Under the applied experimental conditions, the highest unit yield of seeds was observed for the sunflower crop grown on an L-type soil, that showed a higher seed yield per plant, by $6.7 \%$ on average, as compared to the crop grown on soil B, despite the reduction in 1000 seed weight, by $12 \%$ on average, that has been largely compensated by the higher number of seeds per head. Conversely a decrease in seed oil yield, by $4.7 \%$ on average, levelled off the oil yields obtained from the crops grown in the 2 soils (Tab. 3).

The higher leaching fraction (L.R. $=20 \%$ ) generally resulted in a significant increase of the yield parameters under test, as compared to the crop submitted to $10 \%$ L.R. Higher L.Rs. were associated with a $7 \%$ mean increase in the seed number per head, a $24 \%$ increase in the 1000 seed weight that induced an over $10 \%$ mean augmentation in seed yield per plant, and an additional $0.5 \%$ higher oil yield (Tab. 3 ).

As to the fatty acid composition, small but significant differences were observed between the two soils; actually, for the sunflower crop grown in the L soil, low but significant increases in the palmitic, oleic, and linoleic acids, and in the oleic/linoleic ratio were observed, with low significant decreases in myristic, stearic, linoleic, eicosenoic, and behenic acids, and in the (oleic + stearic)/palmitic ratio, as compared to the crop grown in soil B (Tab. 4, Fig. 1). 
Table 4. Effects of the soil type, leaching requirement (L.R.), salt concentration and SAR of irrigation water on the fatty acid composition of sunflower oil.

\begin{tabular}{|c|c|c|c|c|c|c|c|c|c|c|}
\hline \multirow[t]{2}{*}{$\begin{array}{l}\text { Fatty } \\
\text { Acids }\left({ }^{1}\right)\end{array}$} & \multicolumn{2}{|c|}{ Soil types } & \multicolumn{2}{|c|}{ L.R. (\%) } & \multicolumn{3}{|c|}{$\begin{array}{l}\text { Salt concentration of } \\
\text { irrigation water }(\mathrm{M})\end{array}$} & \multicolumn{3}{|c|}{$\begin{array}{l}\text { SAR of irrigation } \\
\text { water }\end{array}$} \\
\hline & B & $\mathrm{L}$ & 10 & 20 & 0.01 & 0.032 & 0.064 & 5 & 15 & 45 \\
\hline $14: 0$ & $0.11 \mathrm{~A}$ & $0.09 \mathrm{~B}$ & $0.103 \mathrm{~A}$ & $0.096 \mathrm{~B}$ & $0.101 \mathrm{~A}$ & $0.099 \mathrm{~A}$ & $0.098 \mathrm{~A}$ & $0.111 \mathrm{~A}$ & $0.98 \mathrm{AB}$ & $0.09 \mathrm{~B}$ \\
\hline $16: 0$ & $6.0 \mathrm{~B}$ & $6.4 \mathrm{~A}$ & $6.2 \mathrm{~B}$ & $6.3 \mathrm{~A}$ & $6.6 \mathrm{~A}$ & $6.2 \mathrm{~B}$ & $5.9 \mathrm{C}$ & $6.3 \mathrm{~A}$ & $6.2 \mathrm{~B}$ & $6.1 \mathrm{C}$ \\
\hline 18:0 & $3.7 \mathrm{~A}$ & $3.5 \mathrm{~B}$ & $3.9 \mathrm{~A}$ & $3.3 \mathrm{~B}$ & $4.0 \mathrm{~A}$ & $3.6 \mathrm{~B}$ & $3.3 \mathrm{C}$ & $3.7 \mathrm{~A}$ & $3.7 \mathrm{~A}$ & $3.5 \mathrm{~B}$ \\
\hline $18: 1$ & $49.3 \mathrm{~B}$ & $49.6 \mathrm{~A}$ & $50.4 \mathrm{~A}$ & $48.5 \mathrm{~B}$ & $47.6 \mathrm{C}$ & 49.3B & $51.0 \mathrm{~A}$ & $48.9 \mathrm{C}$ & 49.4B & $50.0 \mathrm{~A}$ \\
\hline $18: 2$ & $39.8 \mathrm{~A}$ & 39.3B & 38.3B & $40.7 \mathrm{~A}$ & 41.0A & $39.6 \mathrm{~B}$ & $38.2 \mathrm{C}$ & 39.9A & $39.5 \mathrm{~B}$ & $39.1 \mathrm{C}$ \\
\hline $18: 3$ & 0.11B & $0.12 \mathrm{~A}$ & $0.12 \mathrm{~A}$ & $0.12 \mathrm{~A}$ & 0.10B & 0.13A & 0.13B & 0.12B & 0.13A & 0.12B \\
\hline 20:0 & $0.27 \mathrm{~A}$ & $0.26 \mathrm{~A}$ & $0.27 \mathrm{~A}$ & $0.25 \mathrm{~B}$ & $0.32 \mathrm{~A}$ & $0.25 \mathrm{~B}$ & $0.23 \mathrm{C}$ & $0.28 \mathrm{~A}$ & $0.27 \mathrm{~B}$ & $0.25 \mathrm{C}$ \\
\hline $20: 1$ & $0.21 \mathrm{~A}$ & $0.15 \mathrm{~B}$ & $0.20 \mathrm{~A}$ & $0.16 \mathrm{~B}$ & $0.16 \mathrm{C}$ & $0.18 \mathrm{~B}$ & $0.20 \mathrm{~A}$ & $0.16 \mathrm{~B}$ & $0.19 \mathrm{~A}$ & $0.19 \mathrm{~A}$ \\
\hline $22: 0$ & $0.34 \mathrm{~A}$ & $0.28 \mathrm{~B}$ & $0.32 \mathrm{~A}$ & $0.29 \mathrm{~B}$ & $0.33 \mathrm{~A}$ & $0.30 \mathrm{~B}$ & $0.31 \mathrm{~B}$ & $0.32 \mathrm{~A}$ & $0.31 \mathrm{~A}$ & $0.29 \mathrm{~B}$ \\
\hline $18: 1 / 18: 2$ & $1.2 \mathrm{~B}$ & $1.3 \mathrm{~A}$ & $1.3 \mathrm{~A}$ & $1.2 \mathrm{~B}$ & $1.16 \mathrm{C}$ & $1.25 \mathrm{~B}$ & $1.34 \mathrm{~A}$ & $1.23 \mathrm{C}$ & $1.25 \mathrm{~B}$ & $1.28 \mathrm{~A}$ \\
\hline$(18: 1+18: 0) / 16: 0$ & $8.8 \mathrm{~A}$ & $8.3 \mathrm{~B}$ & $8.8 \mathrm{~A}$ & $8.2 \mathrm{~B}$ & $7.8 \mathrm{C}$ & $8.5 \mathrm{~B}$ & $9.2 \mathrm{~A}$ & $8.3 \mathrm{C}$ & $8.6 \mathrm{~B}$ & $8.8 \mathrm{~A}$ \\
\hline
\end{tabular}

(1) Fatty acids: $14: 0=$ myristic acid; $16: 0=$ palmitic acid; $18: 0=$ stearic acid; $18: 1=$ oleic acid; 18:2 = linoleic acid; $18: 3=$ linolenic acid; 20:0 = arachidic acid; 20:1 = eicosenoic acid; 22:0 = behenic acid.

For each effect considered, the values followed by the same letter are not significantly different, according to the SNK test at $\mathrm{P} \leq$ 0.01 .

Higher variations were instead found in the composition of sunflower oil fatty acids as influenced by the leaching requirement, with a salt stress response similar to that of water stress. With 10\% L.R., significant increases were observed in nearly all tested acids and in the oleic/linoleic and (oleic + stearic)/palmitic ratios, except the reductions observed for the palmitic and linoleic acids, as compared to the crop submitted to a higher leaching requirement (Tab. 4, Fig. 1). The results on the increase in the oleic/linoleic acid ratio associated with the reduction in the L.R. are in agreement with Talha and Osman (1974) who observed a clear trend on the increase of the oleic/linoleic acid ratio under water stress. In high-oleic genotypes too, the water stress applied at seed filling stage

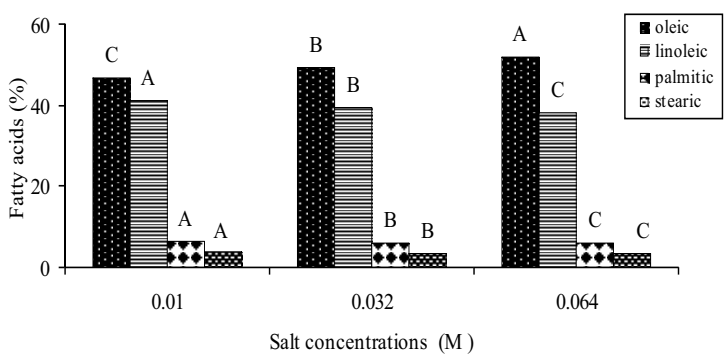

Figure 2. Variation in the oleic, linoleic, palmitic and stearic acids in the oil of a sunflower hybrid (HS90) irrigated with water of different salt concentrations. Values in a row followed by the same letter are not significantly different, according to the SNK test at $\mathrm{P} \leq 0.01$. increases the oleic/linoleic acid ratio in sunflower both in Northern (Baldini et al., 2000) and Southern Italy (Flagella et al., 2000).

\subsection{Effect of irrigation water salt concentration}

The response of sunflower conventional hybrid (HS 90) to the variation in irrigation water salt concentration was similar in the 2 soils submitted to the 2 leaching requirements. Actually, a progressive decline in seed yield has always been observed as the salt stress increased. A similar trend was also observed both for the mean seed weight and for the head size and number of seeds per head. In particular, shifting from the crop irrigated with water of low salt concentration $(0.01 \mathrm{M})$ to that irrigated with water of 0.032 and $0.064 \mathrm{M}$, the mean number of seeds per head decreased by 7.2 and $52 \%$ respectively, their mean weight decreased by 5 and $49 \%$, thus resulting in 12 and $76 \%$ seed yield reductions (Tab. 3). Francois (1996) attributed the reduced yield of a sunflower crop submitted to a salt stress $\left(<10.2 \mathrm{dSm}^{-1}\right.$ of ECe $)$ to the lower number of seeds per head due, in turn, to the head size and to the number of aborted flowers or seeds per inflorescence, whereas no notable difference was observed in the mean seed weight. Moreover, the seed oil percent also decreased with a higher salt concentration of the irrigation water, thus reducing considerably the oil yield per plant, which dropped by 8.2 and $29.5 \%$ respectively when ir- 


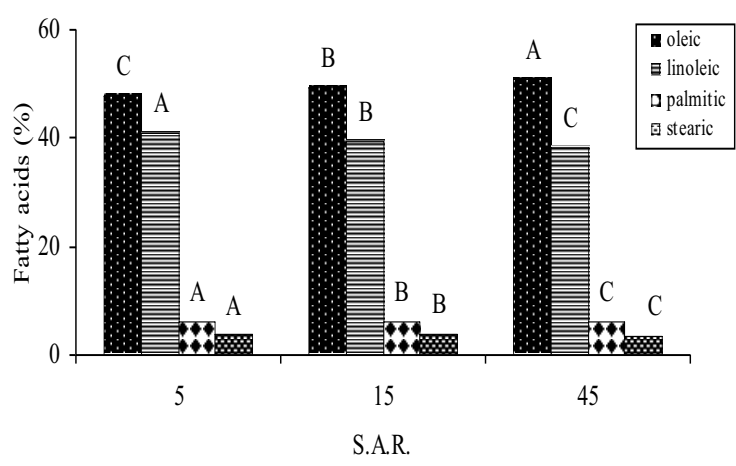

Figure 3. Variation in the oleic, linoleic, palmitic and stearic acids in the oil of a sunflower hybrid (HS90) irrigated with water of different SAR values. Values in a row followed by the same letter are not significantly different, according to the SNK test at $\mathrm{P} \leq 0.01$.

rigated with waters of 0.032 and $0.064 \mathrm{M}$, as compared to the crop irrigated with water of lower salt concentration. These results are in agreement with what is reported for this species under salt stress conditions by Flagella et al. (2000). Francois (1996), instead, did not observe any reduction in oil percent yields, in an experimental trial involving the comparison between 2 sunflower hybrids grown in a saline environment, till soil conductivity values below $10.2 \mathrm{dS} \mathrm{m}^{-1}$.

As to the fatty acid composition, the largest differences were found for the oleic, linoleic, palmitic and stearic acids. In particular as the salt stress became more severe, a progressive increase in the oleic acid content $(7.1 \%$ on average) was observed with corresponding reductions in the linoleic, palmitic and stearic acids equal to $6.8,10.6$ and $17.5 \%$, respectively, with a subsequent increase in the oleic/linoleic and (oleic + stearic)/palmitic acids, as reported by Flagella et al. (2001) under water deficit conditions in Southern Italy, and by Baldini et al. (1999) in Northern Italy. Small but significant variations were also observed for the acids of high number of carbon atoms (20:0, 20:1, 22:0); no significant variation was instead found for the myristic acid (14:0) (Tab. 4, Fig. 2).

\subsection{Effect of the SAR of irrigation water}

The yield traits under test have not been significantly affected by the SAR level of the irrigation water. The oil yield, instead, decreased progressively as the sodium stress was more se- vere. In particular, shifting from the crop irrigated with water characterised by the SAR value of 5 to SAR values of 15 and 45, the oil yield dropped by 2.9 and $6.5 \%$ respectively.

As to the fatty acid composition, a more marked significant effect of the increase in the irrigation water sodium-induced stress was observed on the contents in palmitic, oleic, linoleic and arachidic acids and on the oleic/linoleic and (oleic + stearic)/palmitic acid ratios. In particular a progressive increase, by $2.2 \%$, in the oleic acid content, and a corresponding decrease in the contents of linoleic, by $2 \%$, and palmitic, by $3.2 \%$, acids were associated with a severe sodium-induced stress shifting from SAR 5 to 45. Consequently the oleic/linoleic, and (oleic + stearic)/palmitic ratios increased with the sodium-induced stress, thus improving the oil food quality (TaB. 4, Fig. 3).

\section{Conclusions}

This research showed that in Mediterranean environment the soil type and cultural practices such as irrigation with sodic-saline water and the application of leaching water can cause variation in the oil yield and in the fatty acid ratios oleic/linoleic and (oleic + stearic)/palmitic, which are claimed to be indicators of good quality for sunflower oil. In the 2 soil types studied, opposite variations were observed in seed yield and oil yield; actually the lower amount of seeds obtained in the less calcareous and sesquioxidepoor soil has been compensated by a higher oil yield, as compared to the more calcareous and sesquioxide-rich soil.

As for the acidic profile, a somewhat better quality was obtained in the oil produced in the more calcareous and sesquioxide richer soil. The low leaching fraction has also favoured the oil food quality, whereas the high leaching fraction has favoured the seed yield.

The salt and sodium-induced stresses of irrigation water reduced the seed and oil yields while still favouring a progressive increase in the oleic acid content and a slight decrease of linoleic, palmitic and stearic acids, thus improving oil quality.

The results point out both the influence of the soil and the positive effect of sodium and salt stress and of the leaching fraction on the food quality of sunflower oil. 


\section{Acknowledgements}

This work is part of the cooperative research programme n MM07033154 co-financed by the Ministero dell'Università e della Ricerca Scientifica e Tecnologica and the University of Bari.

\section{References}

Anastasi U., Cammarata M., Abbate V. 2000. Yield potential and oil quality of sunflower (oleic and standard) grown between autumn and summer. Ital. J. Agron., 4:23-36.

Anastasi U., Cammarata M., Sortino O., Abbate V. 2001. Comportamento agronomico e composizione lipidica degli acheni di due ibridi di girasole (convenzionale e alto oleico) in risposta a fattori ambientali. Riv. Agron., 35:76-86.

Baldini M., Giovanardi R., Tahamasebi-Enferadi S., Vannozzi P. 1999. Effetti del regime idrico sulla composizione acidica dell'olio di ibridi di girasole normali e ad alto oleico. Proceedings of the XXXIII Congress of the Italian Society of Agronomy, Legnaro, Italy, 216-217.

Baldini M., Giovanardi R., Vannozzi G. 2000. Effect of different water availability on fatty acid composition of the oil in standard and high oleic sunflower hybrids. In: Proceedings of XV International Sunflower Conference, Toulouse, France, 1:79-84.

Cilardi A.M., Ferri D., Lanza F., Lo Savio N., Santamaria P. 1990. Effetti dell'epoca di semina e degli ibridi su resa quanti-qualitativa e contenuto in acidi oleico e linoleico nell'olio del girasole (Helianthus annuus L.) in secondo raccolto. Risultati di una prova effettuata nella Murgia barese. Riv. Agron., 24:250-256.

Cucci G., Rotunno T., Di Caterina R., Lacolla G. 2005. Relazione fra interramento di sanse umide, resa in olio e profilo acidico di semi girasole (Helianthus annuus L.). Proceedings of the XXXVI Congress of the Italian Society of Agronomy, Foggia, Italy, 320-321.

Flagella Z., Rotunno T., Di Caterina R., de Simone G., De Caro A. 2000. Effect of supplementary irrigation on seed yield and oil quality of sunflower (Helianthus annuus L.) grown in a sub-arid environment. In: Proceedings of XV International Sunflower Conference, Toulouse, France, 1:139-144.

Flagella Z., Rotunno T., Tarantino E., Di Caterina R., De Caro A. 2002. Changes in seed yield and oil fatty acid composition of high oleic sunflower ( $\mathrm{He}$ lianthus annuus L.) hybrids in relation to the sowing date and the water regime. Eur. J. Agron., 17:221-230.

Francois L.E. 1982. Narrow row cotton (Gossypium hirsutum L.) under saline conditions. Irrigation Sci., 3:149-156.

Francois L.E., Maas E.V., Donovan T.J., Young V.L. 1986. Effect of salinity on grain yield and quality, vegetative growth, and germination of semi-dwarf and durum wheat. Agron. J., 78:1053-1058.
Francois L.E. 1996. Salinity effect on four sunflower hybrids. Agron. J., 88:215-219.

Garcés R., Garcìa J.M., Mancha M. 1989. Lipid characterization in seeds of a high oleic acid sunflower mutant. Phytochemistry, 28:2597-2600.

Grummer R.R. 1991. Effect of feed on the composition of milk fat. J. Dairy Sci., 74:3244-3257.

Grundy S.M. 1989. Monounsature fatti acids and cholesterol metabolism: implications for dietary recommendations. The Journal of Nutrition, 119:529-533.

Jones O.R. 1984. Yield, water-use efficiency, and oil concentration and quality of dryland sunflower grown in the Southern High Plains. Agron. J., 76:229-235.

Lajara J.R., Diaz U., Quidiello R. 1990. Influence of location and climatic conditions on the fatty acid composition on sunflower seed oil. J. Am. Oil. Chiem. Soc., 67:618-623.

Laureti D., Del Gatto A., Pieri S., Monatti M., Del Pino A.M. 2000. Valutazione di cultivar di girasole alto oleico nell'Italia centrale. L'Informatore Agrario, 56:47-51.

Massart D.L., Vandeginste B.G.M., Deming S.N., Michotte Y., Kaufman L. 1998. Chemometrics: a Textbook. Elsevier, Amsterdam, 374-375.

Miller J.F., Zimmerman D.C., Vick B.A. 1987. Genetic control of high oleic acid content in sunflower oil. Crop. Sci., 27:923-926.

Monotti M., Del Pino A.M., Laureti D., Mazzoncini M., Pieri S. 1999. Valutazione di varietà di girasole coltivate in Italia nel 1998. L'Informatore Agrario, 55:10-19.

Monotti M. 2002. Tecniche agronomiche per il miglioramento della produzione di olio di girasole ad alto contenuto di acido oleico. Riv. Agron., 36:69-76.

Monotti M. 2004. Growing non-food sunflower in dryland conditions. Ital. J. Agron., 8:3-8.

Pritoni G., Amaducci M.T., Venturi G. 1999. Accumulo di acido oleico in girasole in funzione di disponibilità azotata ed epoca di semina. Proceedings of the XXXIII Congress of the Italian Society of Agronomy, Legnaro, Italy, 214-215.

Rivelli A.R., Albrizio R. 2005. Risposta fisiologica del girasole e dello zucchino allevati in condizioni di salinità. Proceedings of the XXXVI Congress of the Italian Society of Agronomy, Foggia, Italy, 186-187.

Rivelli A.R., Coccaro R. 2005. Impiego di un sistema idroponico nello studio fisiologico dello stress salino del girasole. Proceedings of the XXXVI Congress of the Italian Society of Agronomy, Foggia, Italy, 188-189.

Robertson J.A., Morrison W.H., Wilson R.L. 1978. Effect of sunflower hybrid or variety and planting location on oil content and fatty acid composition. Proc. $8^{\text {th }}$ Internt. Sunflower Conf.. Minneapolis, Minnesota, USA, 524-532.

Quaglietta Chiarandà E., D'Andria R. 1994. Effect of different irrigation scheduling on yield and water uptake of a sunflower crop (Helianthus annuus L.). Eur. J. Agron., 3:53-60. 
Santonoceto C., Anastasi U., Riggi E., Abbate V. 1999. Dinamica di accumulo della sostanza secca dell'olio e dei principali acidi grassi negli acheni di girasole (Helianthus annuus L.) in rapporto al genotipo ed al regime idrico. Proceedings of the XXXIII Congress of the Italian Society of Agronomy, Legnaro, Italy, 212-213.

Santonoceto C., Anastasi U., Riggi E., Abbate V. 2003. Accumulation dynamics of dry matter, and major fatty acids in sunflower seeds in relation to genotype and water regime. Ital. J. Agron., 7:3-14.

Sifola M.I., Caputo R., Mori M., Quaglietta Chiarandà F. 2005. Effetto della concimazione azotata sulla risposta fisiologica e produttiva del girasole. Proceedings of the XXXVI Congress of the Italian Society of Agronomy, Foggia, Italy, 139-140.
Tedeschi P., D'Andria R., Lavini A., Giorgio P., Sorrentino G., Romano G. 1997. Effetto dell'irrigazione con acqua salina sulla resa in granella e olio, sullo stato idrico e sulla fotosintesi fogliare di una coltura in pieno campo di girasole (Helianthus annuus L.). Irrig. Dren., 44:45-49.

Talha M., Osman E. 1974. Effect of soil water stress on water economy and oil composition in sunflower (Helianthus annuus L.). J. Agr. Sci., 84:49-56.

Trémolieres A., Jacques R. 1984. Effets de la lumiére et de la temperature sur la composition en acides gras des graines de colza et de tournesol. C.R. Acad. Agri. de France, 70:510-516.

Yodice R. 1990. Nutritional and stability characteristics of high oleic sunflower seed oil. Fett Wiss. Technol., 92:121-126. 